\title{
Application of TLC-Densitometry for Analysis of Estradiol Hemihydrate in Dosage Forms
}

\author{
Dobrina Doncheva Tsvetkova1, Danka Petrova Obreshkova ${ }^{1,2}$, Stefka Achkova Ivanova ${ }^{1,2}$, \\ Bozhidarka Hadjieva ${ }^{3}$, Peter Yordanov Atanasov ${ }^{4}$
}

${ }^{1}$ Medical University-Sofia, Faculty of Pharmacy, Department of Pharmaceutical Chemistry,

${ }^{2}$ Medical University-Plovdiv, Faculty of Pharmacy, Department of Pharmacognosy and Pharmaceutical Chemistry, 15A Vasil Aprilov Str., Plovdiv 4002, BULGARIA.

${ }^{3}$ Medical University-Plovdiv, Medical College, 15A Vasil Aprilov Str., Plovdiv 4002, BULGARIA.

${ }^{4}$ Clinic of Internal Diseases UMHATEM "N. I. Pirogov"-SOFIA, BULGARIA.

\begin{abstract}
The aim of current study was the application of validated TLC-densitometric method for identification and determination of Estradiol hemihydrate in dosage forms. The applied TLC conditions were: Silicagel $G_{60} F_{254}$ glass plates; mobile phase: chloroform : acetone $=90: 10 \mathrm{v} / \mathrm{v}$, migration distance of mobile phase: $120 \mathrm{~mm}$, UV-detection at $\lambda=254 \mathrm{~nm}$. All of the experimental results for the content of Estradiol hemihydrate correspond to the respective confidence interval: Estrofem table: $1.78 \mathrm{mg} \div 2.12 \mathrm{mg}$; Femoston F1 table: $1.88 \mathrm{mg} \div 2.2 \mathrm{mg}$; Femoston F2 table: $1.99 \mathrm{mg} \div 2.19 \mathrm{mg}$; Trisequens T1 table: $1.78 \mathrm{mg} \div 2.18 \mathrm{mg}$; Trisequens T2 table: $1.92 \mathrm{mg} \div 2.12 \mathrm{mg}$; Trisequens T3 table: $0.97 \mathrm{mg} \div 1.17 \mathrm{mg}$. The proposed validated TLC-densitometric method is appropriate for quality control of Estradiol hemihydrate in commercially available tablets.
\end{abstract}

Key words: Estradiol hemihydrate, TLC, Densitometry, Tablets, analysis, Determination.

\section{INTRODUCTION}

Osteoporosis is designated as the third socially significant disease in the world, after cardiovascular and oncological diseases and the forecast is to take second place in $2020 .^{1}$ Osteoporosis is caused by the reduced levels of estrogen, which in postmenopausal women are $1 / 10$ of the levels in premenopausal women. $^{2}$ Lowered levels of estrogen lead to: 1) increase of oxidative stress; 2) apoptosis of osteoblasts; 3) rapid loss of bone mass due to increased rate of degradation of the bone tissue by osteoclasts; 4) a long life of osteoclasts compared to osteoblasts; 5) reduction of the absorption and utilization of calcium in bones. ${ }^{3}$ Most pharmacological agents used in the prevention and treatment of osteoporosis reduce bone resorption or delay the total rate of bone turnover. For the prevention of fractures are applied: inhibitors of the activity of osteoclasts - bisphosphonates Rizedronate and Zoledronate, ${ }^{4}$ selective estrogen receptor modulators Bazedoxifene $^{5}$ and Lasofoxifene ${ }^{6}$ parathyroid hormone, ${ }^{7}$ Strontium ranelate ${ }^{8}$ and anti-resorptive agent Denosumab - a human monoclonal antibody $\operatorname{IgG}_{2} .{ }^{9}$ Bisphosphonates cause adverse effects on gastrointestinal tract $^{10}$ : nausea, heartburn, scleritis and iritis (Alendronate). ${ }^{11}$ Selective estrogen receptor modulators Bazedoxifene ${ }^{12}$ and Raloxifene ${ }^{13}$ reduce resorption activity by inhibition of the production of interleukin 6, tumor necrosis factor $\alpha$ and the number of osteoclasts. Preclinical studies indicate that Strontium ranelate has a dual mechanism of action: 1) induces the bone formation by synthesis of bone collagen, alkaline phosphatase and osteocalcin; 2) inhibits the osteoclastogenesis by suppressing the differentiation and activity of osteoclasts. ${ }^{14}$
Submission Date : 23-04-2016 Revision Date : :20-06-2016 Accepted Date : 23-06-2016

DOI: 10.5530/ijper.50.3.23

Correspondence:

Dobrina Tsvetkova,

Department of Pharmaceutical Chemistry,

Faculty of Pharmacy,

Medical University-Sofia,

Dunav str. N : 2, 1000, Sofia, BULGARIA.

Tel no: +359029236566

E-mail: dobrinka30@abv.bg

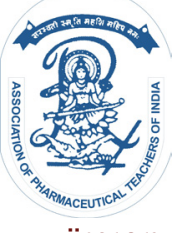

www.ijper.org 
Hormonal therapy reduces the risk of osteoporotic fractures and improves the bone mineral density. ${ }^{15,16}$

Several methods have been reported for the determination of $17 \beta$-Estradiol: UV-spectrophotometry, high performance liquid chromatography (HPLC) ${ }^{17}$ thin layer chromatography (TLC) ${ }^{18}$ and voltametry. ${ }^{19}$ Literature review reveals that HPLC methods are very often applied for the estimation of Estradiol hemihydrate. ${ }^{17}$

For the quantification of $17 \beta$-Estradiol alone or in combinations in different pharmaceutical preparations are developed the following methods: I) TLC on Silicagel $\mathrm{G}_{60} \mathrm{~F}_{254}$, mobile phase: benzol : methanol $=9: 1$ $\mathrm{v} / \mathrm{v}:{ }^{18} 17 \beta$-Estradiol; II) RP-HPLC with UV-detection: 1) column Phenomenex $C_{18}(4.6 \mathrm{~mm} \times 250 \mathrm{~mm} \times 5 \mu \mathrm{m})$, mobile phase: methanol : water $=70: 30 \mathrm{v} / \mathrm{v}$, flow rate: $1.0 \mathrm{ml} / \mathrm{min} ., \lambda=281 \mathrm{~nm},{ }^{17}$ 2) $17 \beta$-Estradiol, Estriol and Estrone: column $\mathrm{C}_{18}$ micro Bondapak, isocratic mode, mobile phase: acetonitrile : water $=50: 50 \mathrm{v} / \mathrm{v}$, flow rate: $1 \mathrm{ml} / \mathrm{min}$., column temperature: $30{ }^{\circ} \mathrm{C}, \lambda=205 \mathrm{~nm},{ }^{20}$ 3) $17 \beta$-Estradiol and its degradation products in Estrogel: column Zorbax SB-CN (4.6 mm x $150 \mathrm{~mm}$ x $5 \mu \mathrm{m}$ ), mobile phase: acetonitrile : $0.085 \%$ phosphoric acid : tetrahydrofurane $=27: 63: 10 \mathrm{v} / \mathrm{v}$, flow rate: $1.0 \mathrm{ml} / \mathrm{min}$, $\lambda=225 \mathrm{~nm},{ }^{21}$ 4) $17 \beta$-Estradiol and Estrone in Estrogel: column Supelco Discovery $C_{18}(250 \mathrm{~mm}$ x $3.0 \mathrm{~mm})$, mobile phase: acetonitrile : methanol $:$ water $=23: 24$ : $53 \mathrm{v} / \mathrm{v}$, flow rate: $0.9 \mathrm{ml} / \mathrm{min} ., \lambda=225 \mathrm{~nm},{ }^{22}$ III) HPLC with fluorimetric detection: $17 \beta$-Estradiol and Estriol at $\lambda$ excitation $=280 \mathrm{~nm}$ and $\lambda$ emission $=312 \mathrm{~nm},{ }^{23} \mathrm{IV}$ ) NP-HPLC with mas detection with atmospheric pressure photoionization, ${ }^{24} \mathrm{~V}$ ) fluorimetry after derivatization reaction with dansylchloride, ${ }^{25} \mathrm{VI}$ ) electrochemical methods with: 1) glass carbon electrode, modified with electropolymerized pyrrole, ${ }^{26}$ 2) poly(L-serine)-filmmodified electrode $\left.{ }^{27} 3\right)$ linear sweep voltammetry. ${ }^{28} \mathrm{In}$ our previous work TLC-densitometric method was validated in accordance with analytical parameters: linearity, limit of detection (LOD), limit of quantitation (LOQ), accuracy and precission (repeatability). ${ }^{29}$ The aim of current study was the application of the validated TLCdensitometric method for identification and determination of Estradiol hemihydrate in dosage forms.

\section{MATERIALS}

\section{Drug products tablets}

Estrofem table (EF70064, Nono Nordisk, Danemark): Estradiol hemihydrate $2 \mathrm{mg}$

Femoston F1 table (341141, Abbott, Netherlands): Estradiol hemihydrate $2 \mathrm{mg}$
Femoston F2 table (341141, Abbott, Netherlands): Estradiol hemihydrate $2 \mathrm{mg}$; Didrogesterone $10 \mathrm{mg}$ Trisequence T1 table (DF 70298, Nono Nordisk, Danemark): Estradiol hemihydrate $2 \mathrm{mg}$

Trisequence T2 table (DF 70298, Nono Nordisk, Danemark): Estradiol hemihydrate $2 \mathrm{mg}$; Noretisterone acetate $1 \mathrm{mg}$

Trisequence T3 table (DF 70298, Nono Nordisk, Danemark): Estradiol hemihydrate $1 \mathrm{mg}$

Reference standard: Estradiol hemihydrate substance, batch N: D00 166536.

Reagents with analytical grade quality: chloroform (Sigma Aldrich, N: SZBD 074SV UN 1888); acetone (Sigma Aldrich, N: SZBC 1861 SV); $99.98 \%$ ethanol (Sigma Aldrich, N: SZBD 0500V UN 1170), distilled water.

\section{METHODS}

\section{TLC-densitometry}

Instrumentation: Densitometer VILBER LOURMAT CN-15.LC Serial: 16263; sample applicator $10 \mathrm{ml}$ micropipette (Hamilton, Bonaduz, Switzerland, N:18005701); TLC glass chamber $(22 \mathrm{~cm} \times 12 \mathrm{~cm} \times 22 \mathrm{~cm})$; stationary phase: TLC glass plates, $20 \mathrm{~cm} \times 20 \mathrm{~cm}$ (Sigma Aldrich, $\mathrm{N}$ : 2364681) were used.

Chromatographic conditions: stationary phase: TLC glass plates precoated with Silicagel $\mathrm{G}_{60} \mathrm{~F}_{254}$, mobile phase: chloroform : acetone $=90: 10 \mathrm{v} / \mathrm{v}$, migration distance of mobile phase: $120 \mathrm{~mm}$, UV-detection at $\lambda=254 \mathrm{~nm}$.

\section{Preparation of test solutions from dosage formulations (tablets), containing Estradiol hemihydrate for the investigation of analytical parameter precision (repeatability)}

Separately from every drug formulation 20 tablets were weighed accurately. From homogenous powdered tablets from every drug preparation on an analytical balance accuratelly were weighed 6 samples, containing an amount equivalent respectively to $10 \mathrm{mg}$ (Trisequence T3 table) and $20 \mathrm{mg}$ (Estrofem table, Femoston F1 table, Femoston F2 table, Trisequence T1 table, Trisequence T2 table) Estradiol hemihydrate. Every sample was transferred separately to a $10.0 \mathrm{ml}$ volumetric flask and was diluted with $99.98 \%$ ethanol. The solutions were filtered through a blue band filter and were analyzed by the densitometric method described.

Chromatographic procedure: Chromatographic analysis was achieved by using glass TLC plates. From every solution separatelly were spotted aliquot parts of $10 \mu \mathrm{l}$ onto glass plates Silicagel $\mathrm{G}_{60} \mathrm{~F}_{254}$, keeping $10 \mathrm{~mm}$ 
distance between bands. The plate was developed about at $25 \pm 1^{\circ} \mathrm{C}$ in ascending vertical manner in glass chromatographic chamber, previously presaturated for $1 \mathrm{~h}$ with mobile phase: chloroform: acetone $=90: 10 \mathrm{v} / \mathrm{v}$. The migration distance of the mobile phase in all experiments was $120 \mathrm{~mm}$. The developed plates were dried on air. Densitometric scanning was performed on scanner VILBER LOURMAT CN-15 LC, operated in the absorbance mode at $\lambda=254 \mathrm{~nm}$.

\section{RESULTS}

In recent work the validated TLC-densitometric method was applied for identification and determination of Estradiol hemihydrate in dosage pharmaceutical formulations-tablets. The obtained by TLC-densitometric method chromatograms of tablets were presented as follows: Estrofem table, Femoston F1 table, Femoston F2 table (Figure 1), Trisequens T1 table and Trisequens T2 table (Figure 2).

On Table 1 are presented the data for the values of Rf and radius $\mathrm{r}[\mathrm{cm}]$ for Estradiol hemihydrate in Estrofem table, Femoston table and Trisequens table. On Table 2 are summarized the results for spot area (A) and Chauvenet's criterion for spot area (UA) and quantity (UC) of Estradiol hemihydrate in Estrofem table, Femoston table and Trisequens table. The amount of Estradiol hemihydrate in Estrofem table (C), Femoston F1 table $\left(\mathrm{C}_{\mathrm{F} 1}\right)$, Femoston $\mathrm{F} 2$ table $\left(\mathrm{C}_{\mathrm{F} 2}\right)$, Trisequens $\mathrm{T} 1$ table $\left(\mathrm{C}_{\mathrm{T} 1}\right)$, Trisequens $\mathrm{T} 2$ table $\left(\mathrm{C}_{\mathrm{T} 2}\right)$ and Trisequens $\mathrm{T} 3$ table $\left(\mathrm{C}_{\mathrm{T} 3}\right)$ (Table 3) was determined by method of calibration curve.

\section{DISCUSSION}

In our previous work a TLC-densitometric method was validated in accordance with International Conference on Harmonization guidelines for validation of analytical procedures for analytical parameters: limearity, LOD, LOQ, accuracy and precission (repeatability). ${ }^{30}$ Placebo solution, containing as supplement starch, without the active substance Estradiol hemihydrate was prepared. The selectivity of the applied method was confirmed by the fact that on chromatogram with placebo preparation did not exist spot with Rf, corresponding to Rf of Estradiol hemihydrate (0.66) in reference standard solution. This fact confirms that there was no interference from the commonly present in tablets excipient starch. The calibration curve was obtained by using the data for different concentrations of standard solutions of Estradiol hemihydrate and was generated by plotting the sample concentration versus the mean peak area. Linear regression analysis was performed. Linearity accordance between the concentration and spot area in range:
$5.10^{-4} \mathrm{~g} / \mathrm{ml} \div 5.10^{-3} \mathrm{~g} / \mathrm{ml}$ was proved by the regression equation: $\mathrm{y}=53256970 . \mathrm{x}-7007(\mathrm{y}-$ peak area, $\mathrm{x}-$ concentration of analyte). The least squares regression yielded a correlation coefficient $\mathrm{R}=0.994$. Limit of detection and limit of quantitation were determined based on the standard deviation of the response and the slope of the regression equation for the calibration curve. The limit of detection, defined the concentration giving a signal with signal to noise ratio of 3 , was $3.91 .10^{-4} \mathrm{~g} / \mathrm{ml}$. The limit of quantitation, defined the concentration giving a signal with signal to noise ratio of 10 , was $1.18 .10^{-3} \mathrm{~g} / \mathrm{ml}$. For the estimation of analytical parameter accuracy the recovery study was carried out by application of the method in triplicate to every to 3 different model mixtures, containing known amount of Estradiol hemihydrate: $75 \%,\left(1.5 \mathrm{mg}, \mathrm{C}_{1.5}\right) ; 100 \%$ $\left(2 \mathrm{mg}, \mathrm{C}_{2}\right) ; 125 \%\left(2.5 \mathrm{mg}, \mathrm{C}_{2.5}\right)$. The content of drug in model mixtures was determined by method of calibration curve using the regression equation. For the assessment of accuracy and precision was calculated sample standard deviation (SD), by the applying of the Bessel's correction, in which the denominator $\mathrm{N}-1$ (degrees of freedom) is used instead of $\mathrm{N}$ and in this case $(\mathrm{S})^{2}$ is an unbiased estimator for (SD). ${ }^{2}$ The results for accuracy at $\mathrm{P}=90 \%(\mathrm{t}=2.92)$, presented by the degree recovery $\mathrm{R}(\%) \pm \mathrm{RSD}(\%)$ suit respective confidence interval: 1$)$ $\left.\mathrm{RC}_{1.5}: 98.75 \% \div 102.13 \%(\mathrm{SD}=1.01) ; 2\right) \mathrm{RC}_{2}: 98.73 \% \div$ $102.93 \%(\mathrm{SD}=1.25) ; 3) \mathrm{RC}_{2.5}: 98.29 \% \div 103.03 \%$ $(\mathrm{SD}=1.4)$. For the estimation of an analytical parameter precision (repeatability) was used the uncertainty of the result, which was determined by: standard deviation (SD), relative standard deviation (RSD) and confidence range. All data for the obtained quantity of Estradiol hemihydrate correspond to the confidence interval: $1.95 \mathrm{mg} \div 2.09 \mathrm{mg}(\mathrm{SD}=0.05) .{ }^{29}$

In current study the indentity of Estradiol hemihydrate in analysed drug formulations was proved by the correspondence between the retardation factors of drug in samples and reference standard $\mathrm{Rf}=0.65$. (Table 1).

For the assessment of the need for the removal of sharply differing data is used the criterion of Chauvent. From Table 2. it is obvious that for all of the analysed tablets the calculated Chauvenet's criterion for the area of the spots (UA) and for the quantities (UC) of Estradiol hemihydrate are lower than the maximum value of the criterion $(\mathrm{Umax}=1.73 ; \mathrm{N}=6)$, which proves that the results suit to the requirements of the criterion for the analysis of 6 separate samples from Estrofem table, Femoston F1 table, Femoston F2 table, Trisequens T1 table, Trisequens T2 table and Trisequens T3 table.

On Table 3. are presented the data for: $\mathrm{N}$ - number of individual measurements $(1 \div 6) ; \overline{\mathrm{X}}$ - mean arithmetic 
Estrofem table

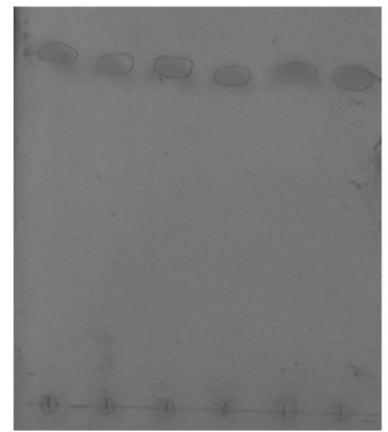

Figure 1: Chromatograms of Estradiol hemihydrate in Estrofem table, Femoston F1 table and Femoston F2 table.

Trisequens T1 table

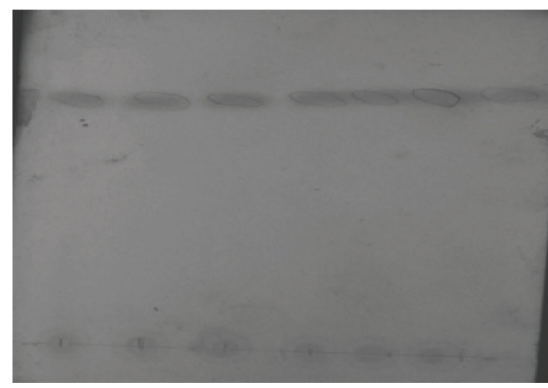

Trisequens T2 table

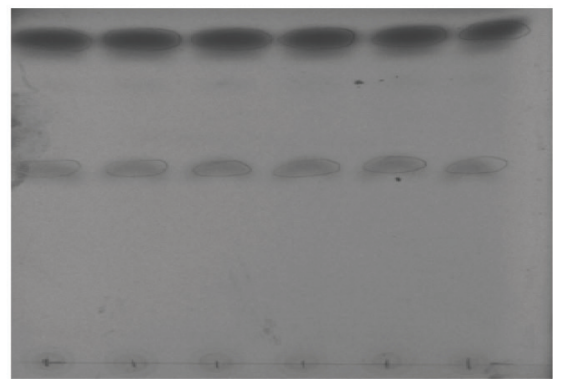

Figure 2: Chromatograms of Estradiol hemihydrate in Trisequens T1 table and Trisequens T2 table.

Table 1: Results for Rf and for Estradiol hemihydrate in Estrofem table, Femoston table and Trisequens table

\begin{tabular}{|c|c|c|c|c|c|c|}
\hline \multirow{2}{*}{$\mathbf{N}:$} & \multicolumn{2}{|c|}{ Estrofem table } & \multicolumn{2}{c|}{ Femoston F1 table } & \multicolumn{2}{c|}{ Femoston F2 table } \\
\cline { 2 - 7 } & $\mathbf{R f}$ & $\mathbf{r}[\mathbf{c m}]$ & $\mathbf{R f}$ & $\mathbf{r}[\mathbf{c m}]$ & $\mathbf{R f}$ & $\mathbf{r}[\mathbf{c m}]$ \\
\hline 1. & 0.64 & 0.23 & 0.65 & 0.255 & 0.65 & 0.25 \\
\hline 2. & 0.64 & 0.23 & 0.64 & 0.23 & 0.66 & 0.26 \\
\hline 3. & 0.65 & 0.25 & 0.65 & 0.255 & 0.66 & 0.26 \\
\hline 4. & 0.65 & 0.25 & 0.65 & 0.25 & 0.66 & 0.25 \\
\hline 5. & 0.64 & 0.24 & 0.65 & 0.25 & 0.66 & 0.26 \\
\hline 6. & 0.65 & 0.25 & 0.64 & 0.24 & 0.65 & 0.25 \\
\hline $\mathbf{N}:$ & Trisequens T1 $\mathbf{t a b l e}$ & Trisequens T2 table & Trisequens T3 table \\
\cline { 2 - 7 } & $\mathbf{R f}$ & $\mathbf{r}[\mathbf{c m}]$ & $\mathbf{R f}$ & $\mathbf{r}[\mathbf{c m}]$ & $\mathbf{R f}$ & $\mathbf{r}[\mathbf{c m}]$ \\
\hline 1. & 0.64 & 0.23 & 0.65 & 0.25 & 0.65 & 0.15 \\
\hline 2. & 0.65 & 0.25 & 0.65 & 0.25 & 0.64 & 0.14 \\
\hline 3. & 0.63 & 0.225 & 0.64 & 0.24 & 0.65 & 0.15 \\
\hline 4. & 0.65 & 0.25 & 0.65 & 0.25 & 0.66 & 0.16 \\
\hline 5. & 0.64 & 0.24 & 0.65 & 0.25 & 0.64 & 0.14 \\
\hline 6. & 0.65 & 0.25 & 0.65 & 0.25 & 0.65 & 0.15 \\
\hline
\end{tabular}




\begin{tabular}{|c|c|c|c|c|c|c|c|c|c|}
\hline \multirow[t]{2}{*}{ N: } & \multicolumn{3}{|c|}{ Estrofem table } & \multicolumn{3}{|c|}{ Femoston F1 table } & \multicolumn{3}{|c|}{ Femoston F2 table } \\
\hline & A & UA & UC & A & UA & UC & A & UA & UC \\
\hline 1. & 88000 & 1.44 & 1.42 & 106200 & 0.81 & 0.82 & 99100 & 1.24 & 1.25 \\
\hline 2. & 91800 & 0.84 & 0.75 & 92900 & 1.45 & 1.45 & 107500 & 0.70 & 0.75 \\
\hline 3. & 100500 & 0.54 & 0.58 & 107300 & 1.0 & 1.0 & 108400 & 0.91 & 1.0 \\
\hline 4. & 102400 & 0.84 & 0.83 & 102700 & 0.22 & 0.18 & 100600 & 0.89 & 0.88 \\
\hline 5. & 95900 & 0.19 & 0.17 & 95500 & 1.01 & 1.09 & 109000 & 1.04 & 1.13 \\
\hline 6. & 104000 & 1.09 & 1.08 & 104000 & 0.44 & 0.36 & 102200 & 0.52 & 0.5 \\
\hline $\bar{x}$ & 97100 & & & 101433 & & & 104467 & & \\
\hline SD & 6318 & & & 5888 & & & 4339 & & \\
\hline RSD [\%] & 6.51 & & & 5.80 & & & 4.15 & & \\
\hline \multirow[t]{2}{*}{ N: } & \multicolumn{3}{|c|}{ Trisequens T1 table } & \multicolumn{3}{|c|}{ Trisequens T2 table } & \multicolumn{3}{|c|}{ Trisequens T3 table } \\
\hline & A & UA & UC & A & UA & UC & A & UA & UC \\
\hline 1. & 93000 & 0.8 & 0.83 & 98100 & 0.83 & 0.83 & 50200 & 0.06 & 0 \\
\hline 2. & 101700 & 0.55 & 0.5 & 100800 & 0.005 & 0 & 45200 & 1.46 & 1.5 \\
\hline 3. & 88500 & 1.5 & 1.58 & 95900 & 1.52 & 1.5 & 51700 & 0.51 & 0.5 \\
\hline 4. & 103300 & 0.8 & 0.75 & 102400 & 0.5 & 0.5 & 53500 & 1.05 & 1.17 \\
\hline 5. & 97400 & 0.12 & 0.17 & 103200 & 0.75 & 0.83 & 46900 & 0.94 & 1.0 \\
\hline 6. & 105100 & 1.08 & 1.08 & 104300 & 1.09 & 1.17 & 52600 & 0.78 & 0.83 \\
\hline $\bar{x}$ & 98167 & & & 100783 & & & 50017 & & \\
\hline SD & 6444 & & & 3221 & & & 3304 & & \\
\hline RSD [\%] & 6.56 & & & 3.2 & & & 6.61 & & \\
\hline
\end{tabular}

\begin{tabular}{|c|c|c|c|c|c|c|}
\hline \multirow[t]{2}{*}{ N: } & \multirow{2}{*}{$\begin{array}{c}\text { Estrofem table } \\
\text { C }\end{array}$} & \multicolumn{2}{|c|}{ Femoston table } & \multicolumn{3}{|c|}{ Trisequens table } \\
\hline & & $\mathrm{C}_{\mathrm{F} 1}$ & $\mathrm{C}_{\mathrm{F} 2}$ & $\mathrm{C}_{\mathrm{T} 1}$ & $\mathrm{C}_{\mathrm{T} 2}$ & $\mathbf{C}_{\mathrm{T} 3}$ \\
\hline 1. & 1.78 & 2.13 & 1.99 & 1.88 & 1.97 & 1.07 \\
\hline 2. & 1.86 & 1.88 & 2.15 & 2.04 & 2.02 & 0.98 \\
\hline 3. & 2.02 & 2.15 & 2.17 & 1.79 & 1.93 & 1.10 \\
\hline 4. & 2.05 & 2.06 & 2.02 & 2.07 & 2.05 & 1.14 \\
\hline 5. & 1.93 & 1.92 & 2.18 & 1.96 & 2.07 & 1.01 \\
\hline 6. & 2.08 & 2.08 & 2.05 & 2.11 & 2.09 & 1.12 \\
\hline $\bar{X} \pm S D$ & $\begin{array}{c}1.95 \pm \\
0.12\end{array}$ & $\begin{array}{c}2.04 \pm \\
0.11\end{array}$ & $\begin{array}{c}2.09 \pm \\
0.08\end{array}$ & $\begin{array}{c}1.98 \pm \\
0.12\end{array}$ & $\begin{array}{c}2.02 \pm \\
0.06\end{array}$ & $\begin{array}{c}1.07 \pm \\
0.06\end{array}$ \\
\hline SD & 0.12 & 0.11 & 0.08 & 0.12 & 0.06 & 0.06 \\
\hline RSD [\%] & 0.15 & 5.39 & 3.83 & 6.06 & 2.97 & 5.61 \\
\hline$s \bar{X}$ & 0.05 & 0.04 & 0.03 & 0.05 & 0.024 & 0.024 \\
\hline $\mathrm{P}[\%]$ & 98.0 & 99.0 & 98.0 & 99.0 & 99.0 & 99.0 \\
\hline $\mathrm{t}$ & 3.37 & 4.03 & 3.37 & 4.03 & 4.03 & 4.03 \\
\hline t.s $\bar{X}$ & 0.17 & 0.16 & 0.1 & 0.2 & 0.1 & 0.1 \\
\hline $\begin{array}{l}\bar{X}-t . s \bar{X}, \\
\bar{X}+t . s \bar{X}\end{array}$ & $1.78 \div 2.12$ & $1.88 \div 2.2$ & $1.99 \div 2.19$ & $1.78 \div 2.18$ & $1.92 \div 2.12$ & $0.97 \div 1.17$ \\
\hline E [\%] & 2.56 & 1.96 & 1.44 & 2.53 & 1.19 & 2.24 \\
\hline
\end{tabular}


error; SD - standard deviation; RSD - relative standard deviation (\%); $\mathrm{S} \overline{\mathrm{X}}-$ mean square error; $\overline{\mathrm{X}} \pm$ t.S $\overline{\mathrm{X}}=$ $\overline{\mathrm{X}}-\mathrm{t} . \mathrm{S} \overline{\mathrm{X}}+\mathrm{t} . \mathrm{S} \overline{\mathrm{X}}$ - confidence interval; $\mathrm{E}(\%)$ - relative error. The used values for confidence possibility was $\mathrm{P}=95 \%$ and for coefficient of Student: $\mathrm{t}=2.57$.

\section{CONCLUSION}

The validated TLC-densitometric method was applied for the identification and determination of Estradiol hemihydrate in tablets. The analytical parameter repeatability for the content of Estradiol hemihydrate in tablets was characterized with SD and RSD. The results showed that all of the obtained by method of calibration curve experimental results for the content of Estradiol hemihydrate correspond to the respective confidence inter- val. The proposed validated TLC-densitometric method is appropriate for quality control of Estradiol hemihydrate in commercially available tablets.

\section{ACKNOWLEDGEMENT}

This article was prepared with the financial support from DP N:13/2015, Medical University-Plovdiv, Bulgaria.

\section{CONFLICT OF INTEREST}

The authors contributing to this study and manuscript have no conflict of interests

\section{SUMMARY}

- The aim of current study was the application of validated TLC-densitometric method for identification and determination of Estradiol hemihydrate in dosage forms.

- The applied TLC conditions were: Silicagel $G_{60} F_{254}$ glass plates; mobile phase: chloroform : acetone $=90$ : 10 $\mathrm{v} / \mathrm{v}$, migration distance of mobile phase: $120 \mathrm{~mm}$, UV-detection at $\lambda=254 \mathrm{~nm}$.

- The indentity of Estradiol hemihydrate in analysed drug formulations was proved by the correspondence between the retardation factors of drug in samples and reference standard.

- The content of Estradiol hemihydrate in tablets was determined by method of calibration curve using the regression equation.

- For the estimation of an analytical parameter precision (repeatability) was used the uncertainty of the result, which was determined by: standard deviation (SD), relative standard deviation (RSD) and confidence range.

- All of the experimental results for the content of Estradiol hemihydrate correspond to the respective confidence interval: Estrofem table: $1.78 \mathrm{mg} \div 2.12 \mathrm{mg}$; Femoston F1 table: $1.88 \mathrm{mg} \div 2.2 \mathrm{mg}$; Femoston F2 table: $1.99 \mathrm{mg} \div 2.19 \mathrm{mg}$; Trisequens T1 table: $1.78 \mathrm{mg} \div 2.18 \mathrm{mg}$; Trisequens T2 table: $1.92 \mathrm{mg} \div 2.12 \mathrm{mg}$; Trisequens T3 table: $0.97 \mathrm{mg} \div 1.17 \mathrm{mg}$.

- The proposed validated TLC-densitometric method is appropriate for quality control of Estradiol hemihydrate in commercially available tablets.

\section{REFERENCES}

1. Reginster JY and Burlet N. Osteoporosis: a still increasing prevalence. Bone. 2006;38(2Suppl 1):S4-9.

2. Ejiri S, Tanaka M, Watanabe N, Anwar RB, Yamashita E, Yamada K et al. Estrogen deficiency and its effect on the jaw bone. J Bone Miner Res. 2008;26(5):409-15.

3. Popat VB, Calis KA, Vanderhoof VH, Cizza G, Reynolds JC, Sebring N et al. Bone mineral density in estrogen-deficient young women. J Clin Endocrinol Metab. 2009;94(7):2277-83.

4. Reid DM, Devogelaer JP, Saag K, Roux C, Lau CS, Reginster JY et al. Zoledronic acid and Risedronate in the prevention and treatment of glucocorticoid-induced osteoporosis (HORIZON): a multi-centre, double-blind, double-dummy, randomised controlled trial. Lancet. 2009;373(9671):1253-63.

5. Lindsay R, Gallagher JC, Kagan R, Pickar JH and Constantine G. Efficacy of tissue-selective estrogen complex of Bazedoxifene/conjugated estrogens for osteoporosis prevention in at-risk postmenopausal women. Fertil Steril. 2009;92(3):1045-52.
6. Cummings SR, Ensrud K, Delmas RD, LaCroix AZ, Vukicevic S, Reid DM et al. Lasofoxifene in postmenopausal women with osteoporosis. N Engl J Med. 2009;362(8):686-96 .

7. Cranney A, Papaioannou A, Zytaruk N, Hanley D, Adachi J, Goltzman D et al. Parathyroid hormone for the treatment of osteoporosis: a systematic review. CMAJ. 2006;175(1):52-9.

8. Reginster J, Seeman E, De Vernejoul MC, Adami S, Compston J, Phenekos C et al. Strontium ranelate reduces the risk of non-vertebral fractures in postmenopausal women with osteoporosis: treatment of peripheral osteoporosis (TROPOS) study. J Clin Endocrinol Metab. 2005;90(5):2816-22.

9. Zhou Z, Chen C, Zhang J, Ji X, Liu L, Zhang G et al. Safety of Denosumab in postmenopausal women with osteoporosis or low bone mineral density: a meta-analysis. Int J Clin Exp Pathol. 2014;7(5):2113-22.

10. Cadarette SM, Katz JN, Brookhart MA, Stürmer T, Stedman MR, Levin R et al. Comparative gastro-intestinal safety of weekly oral bisphosphonates. Osteoporos Int. 2009;20(10):1735-47.

11. Odvina CV, Zerwekh JE, Rao DS, Maalouf N, Gottschalk FA and Pak CY. Severely suppressed bone turnover: a potential complication of Alendronate therapy. J Clin Endocrinol Metab. 2005;90(3):1294-301. 
12. Silverman SL, Christiansen C, Genant HK, Vukicevic S, Zanchetta JR, de Villiers TJ et al. Efficacy of Bazedoxifene in reducing new vertebral fracture risk in postmenopausal women with osteoporosis: results from a 3-year, randomised, placebo-, and active-controlled clinical trial. J Bone Miner Res. 2008;23(12):1923-34.

13. Siris ES, Harris ST, Eastell R, Zanchetta JR, Goemaere S, Diez-Perez A et al. Skeletal effects of Raloxifene after 8 years: results from the Continuing Outcomes Relevant to Evista (CORE) study. J Bone Miner Res. 2005;20(9):1514-24.

14. Marie PJ. Strontium ranelate: new insights into its dual mode of action. Bone. 2007;40(5):S5-8.

15. Cauley JA, Robbins J, Chen Z, Cummings SR, Jackson RD, LaCroix AZ et al. Effects of estrogen plus progestin on risk of fracture and bone mineral density: the Women's Health Initiative randomised trial. JAMA. 2003;290(13):1729-38.

16. Gambacciani M and Vacca F. Postmenopausal osteoporosis and hormone replacement therapy. Minerva Med. 2004;95(6):507-20.

17. Yilmaz B and Kadioglu Y. Determination of $17 \beta$-Estradiol in pharmaceutical preparation by UV-spectrophotometry and high performance liquid chromatography methods. Arab J Chem. 2013;2(1):1-7.

18. Dolowy M, Kurowska A and Pyka A. Development and validation of a TLCdensitometry method for assay of Estradiol hemihydrate in tablets. Curr Pharm Anal. 2015;10(2):112-21.

19. Tao H, Wei W, Zeng X, Liu X, Zhang X and Zhang Y. Electrocatalytic oxidation and determination of Estradiol using an electrode modified with carbon nanotubes and an ionic liquid. Microchim Acta. 2009;166(1-2):53-9.

20. Wilson P. Development and validation of a liquid chromatographic method for the simultaneous determination of Estradiol, Estriol, Estrone and Progesterone in pharmaceutical preparations. J AOAC Int. 2009;92(3):846-54.
21. Havlíková L, Nováková L, Matysová L, Sícha J and Solich P. Determination of Estradiol and its degradation products by liquid chromatography. J Chromatogr A. 2006;1119(1-2):216-23.

22. Nováková L, Solich P, Matysová L and Šícha J. HPLC determination of Estradiol, its degradation product, and preservatives in new topical formulation Estrogel HBF. Anal Bioanal Chem. 2004;379(5-6):781-87.

23. Gatti R, Gioia MG, Di Pietra AM and Cavrini V. HPLC-fluorescence determination of unconjugated estrogens in pharmaceuticals. J Pharm Biomed Anal. 1998;18(1-2):187-92.

24. Josephs RD, Daireaux A, Choteau T, Westwood S and Wielgosz RI. Normal phase-liquid chromatography-tandem mass spectrometry with atmospheric pressure photoionization for the purity assessment of $17 \beta$-Estradiol. Anal Bioanal Chem. 2015;407(11):3147-57.

25. Fishman S. Determination of estrogens in dosage forms by fluoroscence using dansyl chloride. J Pharm Sci. 1975;64(4):674-80.

26. Ojeda I, López-Montero J, Moreno-Guzmán M, Janegitz BC, GonzálezCortés A, Yáñez-Sedeño $P$ et al. Electrochemical immunosensor for rapid and sensitive determination of Estradiol. Anal Chim Acta. 2012;743(1):117-24.

27. Yang $\mathrm{J}, \mathrm{Hu} \mathrm{X}$. Electrochemical determination of estradiol using a poly (L-serine) film-modified electrode. J Appl Electrochem. 2008;38(6):833-36.

28. Yilmaz B. Determination of $17 \beta$-Estradiol in pharmaceutical preparations by linear sweep voltammetry method. IJSIT. 2014;3(3):250-58.

29. Pankova St, Tsvetkova D, Ivanov K, Papanov St and Ivanova St. Validation of TLC-densitometric method for identification and determination of Estradiol. Pharmacia. 2015;62(2):3-9.

30. International Conference on Harmonization guidelines. Validation of analytical procedures: text and methodology Q2 (R1): FDA. Fed Regist. 1995;60:11260. 